Niepodległość. Idee, fakty, perspektywy. W 100. rocznicę odzyskania niepodległości przez Polskę, red. P. Krokosz, S. Romański-Cebula, Kraków 2019, s. I5-3I

DOI: http://dx.doi.org/Io.I5633/9788374388085.02

TOMAsz Korban

Uniwersytet Jagielloński

\title{
Działalność niepodległościowa organizacji studenckich na Uniwersytecie Jagiellońskim w latach I897-I9I4
}

\section{Abstrakt}

Warunki polityczne, jakie zaistniały pod koniec XIX wieku w Galicji, części monarchii austro-węgierskiej, przyczyniły się do powstania różnorodnych organizacji młodzieżowych i studenckich, kultywujących tradycje niepodległościowe oraz samokształceniowe. Znajdowały się one pod wpływem tworzących się w tym samym czasie polskich partii politycznych, posiadających zróżnicowane poglądy na kwestię przywrócenia Polsce niepodległości. W artykule omówiono działalność niepodległościową organizacji studenckich na Uniwersytecie Jagiellońskim na przełomie XIX i XX wieku. Studiująca młodzież skupiona była m.in. w następujących organizacjach: Związek Młodzieży Polskiej „Zet”, Niepodległościowa Młodzież Ludowa czy „Spójnia”. Przed wybuchem I wojny światowej studenci angażowali się również w działalność organizacji wojskowych.

Słowa kluczowe:

organizacje studenckie, działalność niepodległościowa, Uniwersytet Jagielloński, Związek Młodzieży Polskiej „Zet”, Niepodległościowa Młodzież Ludowa, „Spójnia”, „Promień”

\section{Abstract}

Independence activity of student organizations at the Jagellonian University in years I897-I9I4.

Political conditions, which came into being at the end of the XIXth century in Galicia, a part of Austria-Hungary monarchy, contributed to the 
beginning of various youth and student organizations which cultivated independence traditions and self-education. They were under the influence of Polish political parties which were formed at same time and possessed different views on the matter of restoration of independence in Poland. The independence activity of student organizations at the the Jagellonian University on the turn of the XIXth and the XXth century is discussed in the article. Studying young people were concentrated, among other things, in the following organizations: Association of Young Polish People "Zet", Independence Folk Young People or "Spójnia". Before the outbreak of the First World War students were also engaged in the activity of military organizations.

Keywords:

student organizations, independence activity, the Jagellonian University, Young Polish People Association "Zet”, Independence Folk Young People, "Spójnia”, "Promień"

Działając w organizacjach i stowarzyszeniach studenckich, łatwiej jest realizować idee i osiągać zakładane cele. Stąd też studenci sami zakładali organizacje lub wstępowali do już istniejących, tworzonych przez starszą część społeczeństwa', w których mogli pracować na rzecz realizacji różnych celów - materialnych, kulturalnych, naukowych czy politycznych. Działalność organizacji studenckich ulega szczególnej zmianie w rzeczywistości społeczno-politycznej, która ogranicza ich swobodę działania. Funkcjonowanie polskich organizacji studenckich w XIX wieku spotykało się z określoną reakcją władz zaborczych, nawet jeżeli nie godziło ono w żaden sposób w zaborcę. Szczególnie lata 80. i 9o. XIX wieku przyniosły popularyzację nowych poglądów politycznych wśród polskich studentów na uczelniach Królestwa Polskiego i Galicji. Młodzi ludzie z reguły byli siłą napędową każdej organizacji, jak również buntów czy protestów². Dlatego też studentów starały się wciągnąć w swoją pracę rodzące się polskie formacje polityczne,

I Por. B. Hillebrandt, Polskie organizacje mtodzieżowe XIX $i$ XX wieku. Zarys historii, Warszawa I986, s. 5 .

2 J. Eisler, „Polskie miesiące”, czyli kryzys(Y) w PRL, Warszawa 2008, s. I I 3-I I4. 
takie jak Liga Narodowa 3 czy ruch socjalistyczny4. Powstawały wreszcie organizacje młodzieżowe, takie jak Związek Młodzieży Polskiej „Zet”, które za swój priorytet uznawały walkę o niepodległość Polski. Również na Uniwersytecie Jagiellońskim zawiązywały się organizacje studenckie, które pośrednio lub bezpośrednio dążyły w swoim programie do odzyskania niepodległości przez Polskę.

Dzieje organizacji studenckich na przełomie XIX i XX wieku są elementem historii poszczególnych uczelni ${ }^{6}$, podobnie jak losy organizacji młodzieżowych, którym poświęcone zostały różne prace. Podstawowe dzieło w tym zakresie pt. Polskie organizacje młodzieżowe XIX $i$ XX wieku. Zarys historii napisał Bogdan Hillebrandt. Praca ta jednak nie wyczerpuje wszystkich wątków, a w szczególności walki o niepodległość Polski. Ukazały się również publikacje pokonferencyjne poświęcone tej tematyce ${ }^{7}$ oraz monografie różnych organizacji młodzieżowo-studenckich, których działalność cechował sprzeciw wobec zaborców i dążenie do odzyskania niepodległości przez Polskę 8 . Podobna tendencja badawcza występuje również w odniesieniu do historii Uniwersytetu Jagiellońskiego w omawianym okresie. Oprócz pozycji, w których obecne są wzmianki na temat postaw polityczno-ideowych wśród studentów9 , a także prac poświęconych polskim organizacjom paramilitarnym, w które zaangażowani byli studenci UJ, takim jak

3 Szerzej o roli studentów w tworzeniu się Ligii Narodowej zob. S. Kozicki, Historia Ligii Narodowej. Okres 1887-1907, Londyn I964, s. 38-45.

4 Szerzej o roli młodych w narodzinach PPS zob. J. Tomicki, Polska Partia Socjalistyczna 1892-1948, Warszawa I983, S. I I-I2.

5 B. Hillebrandt, Polskie organizacje mtodzieżowe..., dz. cyt., s. I6.

6 K. Stopka, A. Banach, J. Dybiec, Dzieje Uniwersytetu Jagiellońskiego, Kraków 2000, s. I24-I 30; J. Miziołek, Uniwersytet Warszawski. Dzieje i tradycja, Warszawa 2005 , S. I83-185.

7 Organizacje młodzieżowe w XX wieku: struktury, ideologia, działalność, red. P. Tomaszewski, M. Wołos, Toruń 2008.

8 P. Waingertner, Konspiracja trzech pokoleń. Związek Młodzieży Polskiej „Zet” i ruch zetowy (1886-1996), Łódź 20I7; B. Halczak, Towarzystwo Tomasza Zana w latach 1899-1914, Zielona Góra I996.

9 H. Barycz, Uniwersytet Jagielloński w życiu narodu polskiego, Wrocław I964, s. Io6-I I4; K. Stopka, A. Banach, J. Dybiec, Dzieje Uniwersytetu Jagiellońskiego, dz. cyt., s. I27. 
Związek Walki Czynnej czy Polskie Drużyny Strzeleckie ${ }^{\mathrm{Io}}$, działalność niepodległościowa organizacji studenckich nie doczekała się opracowania. Dlatego też zasadne wydaje się podjęcie tego zagadnienia.

Celem artykułu jest przybliżenie działalności niepodległościowej organizacji studenckich działających na Uniwersytecie Jagiellońskim w latach I887-I9I4. Wybór pierwszej z cezur został podyktowany powstaniem w tym roku jednej z najbardziej prężnych organizacji, w szeregach której działali studenci UJ - Związku Młodzieży Polskiej „Zet” ${ }^{\text {II }}$. Cezura końcowa to rok wybuchu I wojny światowej, kiedy to większość studentów zaangażowana w działalność niepodległościową organizacji studenckich rozpoczęła swój czynny udział w działaniach zbrojnych, a funkcjonowanie Uniwersytetu z powodu toczących się działań zbrojnych zostało zakłócone ${ }^{\mathrm{I2}}$. Rok I9I4 jest również początkiem militarnej realizacji zakładanej w ubiegłych latach walki o wolność ojczyzny.

Podstawowymi zagadnieniami badawczymi w omawianym temacie są przede wszystkim programy ideowe poszczególnych organizacji, a także formy działalności niepodległościowej. Działania podejmowane przez studentów w ramach organizacji spotykały się z określoną reakcją władz Uniwersytetu. Należy pamiętać, iż studenci, jak również uczelnia funkcjonowały w określonej rzeczywistości politycznej, co powodowało, że władze uniwersyteckie musiały liczyć się z reakcją austriackiego zaborcy.

Podstawą źródłową do niniejszego artykułu są archiwalia znajdujące się w Archiwum Uniwersytetu Jagiellońskiego (AUJ), przede wszystkim poszczególne zespoły poświęcone organizacjom studenckim na Uniwersytecie, a także akta Senatu UJ z omawianego okresu.

Warunki, które determinowały formy działalności poszczególnych organizacji studenckich, wynikały z sytuacji politycznej, w jakiej znalazła się Galicja w drugiej połowie XIX wieku. Wraz z uzyskaniem

\footnotetext{
Io H. Bagiński, U podstaw organizacyjnych Wojska Polskiego 19o8-1914, cz. I, Warszawa I934, passim.

I I P. Waingertner, Konspiracja trzech pokoleń..., dz. cyt., s. 23.

I2 U. Perkowska, Uniwersytet Jagielloński w latach I wojny światowej, Kraków I990, s. 58-59.
} 
w roku i867 przez Galicję autonomii, sytuacja uniwersytetu uległa znacznej poprawie ${ }^{\mathrm{I} 3}$. Po erze germanizacji Uniwersytetu, w I869 roku język polski stał się językiem urzędowym i wykładowym. Równocześnie władze austriackie ustaliły zakres samorządu uniwersyteckiego ${ }^{\mathrm{T4}}$. Nastał więc korzystny okres w historii najstarszego polskiego uniwersytetu, co zaowocowało jego polonizacją i rozwojem pod względem naukowym, jak również wielkościowym. Łącznie w latach ı860-I9ı8 liczba słuchaczy uniwersytetu wzrosła trzynastokrotnie, a studia stały się dostępne również dla kobiet ${ }^{15}$.

Na przełomie XIX i XX wieku uczelnia zaczęła się przekształcać z galicyjskiej w ogólnopolską. Takie zmiany były możliwe dzięki zaangażowaniu stronnictwa stańczyków, grupy krakowskich konserwatystów, widzących przyszłość narodu w pewnych kompromisach z monarchią austro-węgierską ${ }^{\mathrm{I}}$. Fakt ten ułatwił dominację konserwatystów na uniwersytecie, co pod koniec XIX wieku przekładało się również na działalność organizacji studenckich ${ }^{\mathrm{I}}$. Do początku lat 8o. dwoma najważniejszymi organizacjami studenckimi były Czytelnia Akademicka i Towarzystwo Wzajemnej Pomocy „Bratniak” ${ }^{18}$. Pierwsza z nich była organizacją samokształceniową i dyskusyjną. W Czytelni, założonej nielegalnie w I859 roku ${ }^{\mathrm{I} 9}$, a od I867 działającej na mocy nadanego przez namiestnictwo galicyjskie statutu, początkowo dominowały poglądy konserwatywne. Jednak w latach 80 . organizacja coraz bardziej stawała się areną walk pomiędzy dotychczasowym dominującym nurtem zachowawczym a nowymi, radykalnymi poglądami lewicowymi.

I 3 B. Hillebrandt, Polskie organizacje mtodzieżowe..., dz. cyt., s. I 3.

I4 J. Buszko, Społeczno-polityczne oblicze Uniwersytetu $w$ dobie autonomii galicyjskiej (1869-1914), Kraków I963, s. 7.

I5 Z. Tabaka, Analiza zbiorowości studenckiej Uniwersytetu Jagiellońskiego w latach 1850-1918. Studium statystyczne, Kraków I970, s. 90.

I6 Stańczycy. Antologia myśli społecznej i politycznej konserwatystów krakowskich, red. M. Król, Warszawa I982, s. I6-I7.

I7 H. Barycz, Uniwersytet Jagielloński w życiu narodu polskiego, dz. cyt., s. IO6-IO7.

I8 H. Barycz, Uniwersytet Jagielloński w życiu narodu polskiego, dz. cyt., s. Io7.

I9 J. Myśliński, „Ognisko” (1889-189o) na tle losów Czytelni Akademickiej Uniwersytetu Jagiellońskiego, „Rocznik Historii Czasopiśmiennictwa Polskiego” I (I962), s. I85. 
W konsekwencji Czytelnia była kilkukrotnie zamykana przez senat akademicki, a zakres jej swobód za każdym razem się zmniejszał ${ }^{20}$. Druga organizacja - „Bratniak” - miała charakter samopomocowy. Towarzystwo Wzajemnej Pomocy powstało w roku I859, jednak dopiero siedem lat później władze uniwersyteckie zaakceptowały jego istnienie ${ }^{21}$. „Bratniak” niósł pomoc materialną ubogim studentom przez umożliwienie wynajęcia taniego mieszkania w Krakowie, udzielenia pożyczki czy zatrudnienia w jednym z działów Towarzystwa ${ }^{22}$.

Zarówno Czytelnia Akademicka, jak również „Bratniak” nie stawiały za swój cel, choćby jeden z wielu, działań mających przynieść wolność Polsce. Przełom przyniosła w tym zakresie nowa organizacja, mająca znaczenie nie tylko dla Krakowa - Związek Młodzieży Polskiej „Zet”. Była to pierwsza polska organizacja młodzieżowa, której zasięg przekraczał granice zaborów. Na zjazd założycielski w dniach I4-I8 stycznia I877 roku do Krakowa przybyło dziesięciu delegatów reprezentujących Polaków studiujących w zaborze rosyjskim (Uniwersytet Warszawski), austriackim (Uniwersytet Jagielloński, Politechnika Lwowska), a także studiujących na uczelniach zachodnioeuropejskich ${ }^{23}$. „Zet” przyjął strukturę hierarchiczną, działając w ściśle zakonspirowanych warunkach. W swoim programie ideowym łączył hasła sprawiedliwości społecznej ze sprawiedliwością narodową. Tym samym, pomimo związków z powstałą nieco wcześniej Ligą Polską, organizacja uwzględniała również hasła socjalistyczne. Związek w założeniach miał być pewną szkołą myślenia, kształtującą wartości w szeregach swoich członków. Organizacja miała kształcić przyszłych żołnierzy walczących o niepodległość Polski zarówno na gruncie militarnym, jak i moralnym ${ }^{24}$. „Zet” zorganizował między innymi manifestacje patriotyczne z okazji setnej rocznicy uchwalenia Konstytucji 3 maja, a rok I892 ogłosił rokiem żałoby narodowej w związku z rocznicą pod-

20 H. Barycz, Uniwersytet Jagielloński w życiu narodu polskiego, dz. cyt., s. Io8.

2 I W. Jakubas, Towarzystwo Wzajemnej Pomocy Uczniów Uniwersytetu Jagiellońskiego i jego agendy, „Biuletyn Biblioteki Jagiellońskiej” 63 (2013), s. 2 I 3.

22 W. Jakubas, Towarzystwo Wzajemnej Pomocy Uczniów..., dz. cyt., s. 2 I4.

23 B. Hillebrandt, Polskie organizacje mtodzieżowe..., dz. cyt., s. I6.

24 P. Waingertner, Konspiracja trzech pokoleń..., dz. cyt., s. 24. 
pisania konfederacji targowickiej ${ }^{25}$. Kolejna akcja Związku Młodzieży Polskiej „Zet”, upamiętniająca tym razem bitwę pod Racławicami, doprowadziła do fali aresztowań działaczy w Warszawie i ograniczenia działalności organizacji. Z okresu i887-I894, oprócz wzmianek o poszczególnych działaczach „Zetu”, będących studentami Uniwersytetu Jagiellońskiego, nie ma informacji odnośnie do działalności organizacji na najstarszym polskim uniwersytecie. Dominującym ośrodkiem działalności „Zetu” w tym czasie stała się Warszawa, chociaż praca została, jak już wspomniano, sparaliżowana.

Odrodzenie „Zetu” przyniosły działania Ligii Narodowej, której to członkowie widzieli w tej organizacji swoje zaplecze kadrowe. W I898 roku, m.in. pod wpływem prominentnego działacza ZMP Zygmunta Balickiego (I858-I916) ${ }^{26}$ udało się przywrócić działania organizacji ${ }^{27}$. Bardzo szybko prężnymi ośrodkami „Zetu” stały się Lwów i Wrocław. Wydarzenia roku I905, które rozegrały się w zaborze rosyjskim, doprowadziły do zmian zarówno w samym „Zecie”, jak również innych organizacjach niepodległościowych, a także na Uniwersytecie Jagiellońskim.

Strajk szkolny w Królestwie Polskim i represje wobec studentów uczelni warszawskich doprowadziły do napływu na Uniwersytet Jagielloński znacznej ilości młodzieży ${ }^{28}$. W roku akademickim I904/1905 zapisało się I988 słuchaczy, a w kolejnym roku już 279I, co daje wzrost o $40 \%$ w stosunku do poprzedniego roku akademickiego. Co więcej, niemal 31\% studentów stanowiła młodzież „zza kordonu”, czyli z zaboru rosyjskiego ${ }^{29}$. Grupa studentów z Królestwa była bardziej wyrobiona politycznie niż ich koledzy z Galicji. Studenci w Krakowie zareagowali na rewolucję w Królestwie manifestacjami poparcia dla kolegów w zaborze rosyjskim. Strajk spotkał się z różnymi reakcjami polskich stron-

25 P. Waingertner, Konspiracja trzech pokoleń..., dz. cyt., s. 3I.

26 Z. Wojciechowski, Balicki Zygmunt, w: Polski Stownik Biograficzny (dalej PSB), t. I, Kraków I935, s. 233.

27 P. Waingertner, Konspiracja trzech pokoleń..., dz. cyt., s. 35 .

28 H. Barycz, Uniwersytet Jagielloński w życiu narodu polskiego, dz. cyt., s. Io6-I Io.

29 K. Stopka, A. Banach, J. Dybiec, Dzieje Uniwersytetu Jagiellońskiego, dz. cyt., S. I27. 
nictw politycznych. Liga Narodowa odniosła się negatywnie do strajku młodzieży ${ }^{30}$, której lwią część stanowili „zetowcy”. Doprowadziło to do zerwania ZMP z Ligą Narodową w lipcu I9o8 roku . Również w łonie samego „Zetu” doszło do rozłamu. W marcu igog roku zawiązał się we Lwowie tzw. „Zet niezależny”, który początkowo występował jako Polska Młodzież Niepodległościowa. Z czasem od nazwy wydawanego pisma organizację tę zaczęto nazywać „Zarzewiem”32. Organizacja działała początkowo w dwóch niezależnych od siebie ośrodkach - we Lwowie i w Krakowie. Do połączenia organizacji doszło w czasie obchodów 500. rocznicy bitwy pod Grunwaldem w Krakowie. Dokonano wtedy wyboru kierownictwa organizacji, nazwanego Delegacją Naczelnej Ligii Niepodległości. W skład tego organu weszli m.in. studenci Uniwersytetu Jagiellońskiego: Feliks Młynarski (ı884-I972), późniejszy działacz polityczny i wiceprezes Banku Polskiego 33 i Marcin Zieliński (1886-I940), wybitny neurolog i psychiatra $^{34}$. Jedną z form działalności Polskiej Młodzieży Niepodległościowej w Krakowie było kolportowanie ulotek, w których krytykowano gościnne przyjęcie jednego z Habsburgów. Arcyksiążę Karol Franciszek Józef (I887-I922), w latach I9I6-I9ı8 cesarz Karol I, odwiedził Kraków 29 czerwca I9I2 roku35. Organizacja zwracała uwagę na służalczą postawę elit w Królestwie Polskim i zaborze pruskim. Jednak - według organizacji prym w lojalistycznej postawie wiodły władze miasta i uniwersytetu. Dlaczego? Ponieważ na innych ziemiach polskich takie zachowania spotykały się z oporem, natomiast w Galicji - z entuzjazmem. Młodzi ludzie oskarżyli również elity o pogorszenie atmosfery w Krakowie i „plugawienie polskiej duszy cesarską". Oprócz oskarżeń studenci

30 S. Kozicki, Historia Ligii Narodowej..., dz. cyt., s. 249.

3I P. Waingertner, Konspiracja trzech pokoleń..., dz. cyt., s. 43.

32 B. Hillebrandt, Polskie organizacje młodzieżowe..., dz. cyt., s. 24.

33 Z. Landau, Młynarski Feliks, PSB, t. XXI, Kraków I976, s. 443.

34 M. Blombergowa, Uczeni polscy rozstrzelani w Katyniu, Charkowie i Twerze, "Analecta. Studia i Materiały z Dziejów Nauki” 9 (2000) z. 2, s. 42.

35 L. Fiejdasz-Buczek, Bt. cesarz Karol Habsburg (1887-1922). Chrześcijański polityk w stużbie rodziny i narodu, „Roczniki Nauk Prawnych” 26 (20I6) nr I, s. 7I. 
radzili starszym, iż przyszłość Polski nie zależy od cudzego poparcia, ale od własnej siły. Treść ulotki skwitowali stwierdzeniem: „Kto chce żyć - ten walczy i w walce bierze należne mu prawa" ${ }^{36}$. Powyższe słowa jednoznacznie ukazują postawę „zarzewiaków” - byli oni przeciwni wszelkim formom ugody z monarchią austro-węgierską i nastawieni na branie odpowiedzialności za walkę o wolność ojczyzny. Stosunek władz miasta do wizyty arcyksięcia krytykowały również inne organizacje studenckie, takie jak Akademicka Młodzież Narodowa ${ }^{37}$. Działalność Polskiej Młodzieży Niepodległościowej nie ograniczała się tylko do środków werbalnych. „Zarzewiacy” wraz z innymi organizacjami, które w I908 roku opuściły obóz endecki, utworzyli w tymże roku w Krakowie Polski Związek Wojskowy, który stał się punktem wyjścia do tworzenia Polskich Drużyn Strzeleckich ${ }^{38}$. Wraz z wybuchem I wojny światowej zakończyła się historia „Zarzewia”, a jego członkowie walczyli o niepodległość w szeregach Polskiej Organizacji Wojskowej.

Kolejną organizacją studencką, która działała na rzecz niepodległości Polski na Uniwersytecie Jagiellońskim była Niepodległościowa Młodzież Ludowa. W swoich założeniach ideowych organizacja odwoływała się do postulatów Stronnictwa Ludowego. Podobnie jak "zarzewiacy”, członkowie tej organizacji upamiętniali ważne rocznice narodowe, które wykorzystywali do propagowania idei niepodległości, a także postulatów ruchu chłopskiego. Jedną z najważniejszych rocznic, w której upamiętnienie włączyły się również inne organizacje studenckie, były obchody pięćdziesiątej rocznicy wybuchu powstania styczniowego w styczniu I9ı3 roku. Z tej okazji młodzi ludowcy wydali odezwę skierowaną do krakowskich studentów i mieszkańców miasta. Członkowie Niepodległościowej Młodzieży Ludowej wykazywali, że powstanie styczniowe zakończyło się klęską, ponieważ był to zryw szlachecko-mieszczański, który nie objął wszystkich warstw

36 Archiwum Uniwersytetu Jagiellońskiego (dalej: AUJ), S II 785, Polska Młodzież Niepodległościowa, rkps.

37 AUJ, S II 785, Związek Akademicki w Krakowie, Do społeczeństwa polskiego!, druk ulotny.

38 H. Bagiński, U podstaw organizacyjnych Wojska Polskiego..., dz. cyt., s. 2I. 
społecznych narodu polskiego. Niepodległość Polski to jednocześnie wyzwolenie z ucisku chłopów, dlatego -zdaniem Młodzieży Ludowejuświadomieni narodowo chłopi podejmą o nią walkę39.

Rocznica wybuchu powstania styczniowego w I9I3 roku stanowi przykład współpracy różnych organizacji studenckich propagujących niepodległość Polski, ponieważ na 22 stycznia na godzinę I8.00 Niepodległościowa Młodzież Ludowa wraz z Polską Młodzieżą Niepodległościową, Młodzieżą Narodową i Młodzieżą Postępową Niepodległościową zapowiedziały wspólną manifestację przed jednym z budynków Uniwersytetu ${ }^{4}$, prawdopodobnie przed Collegium Novum. Przykład tej inicjatywy pokazuje, że możliwe było porozumienie różnych ideowo organizacji studenckich na rzecz niepodległości. Innym przykładem współdziałania jest również protest przeciwko usunięciu z uczelni przewodniczącego lewicowego „Promienia” Zygmunta Przybylskiego (za przeprowadzenie nielegalnego wiecu), w obronie którego to stanęło m.in. endeckie „Zjednoczenie” ${ }^{\mathrm{r}}$.

Pisząc o rocznicy zrywu narodowego z I863 roku, należy pamiętać, iż w działalność niepodległościową angażowały się również koła naukowe działające na Uniwersytecie. Dzięki pracy kół slawistów i historyków 22 stycznia I9I3 roku zorganizowano tam oficjalne obchody rocznicy wybuchu powstania styczniowego. W programie uroczystości można było znaleźć m.in. wykład Wacława Tokarza (1873-1937) ${ }^{42}$ o udziale studentów UJ w bitwie pod Miechowem w i863 roku, czy też wystąpienie chóru akademickiego ${ }^{43}$.

Kwestia niepodległości Polski potrafiła, jak już pokazał to przykład Związku Młodzieży Polskiej, również dzielić. Innym tego typu przypadkiem były organizacje z drugiej strony ideowej.

39 AUJ, S II 785, Niepodległościowa Młodzież Ludowa (dalej: NML), Koledzy i obywatele!, druk ulotny.

40 AUJ, S II 785, NML,, W pięćdziesiątą rocznicę nocy...., druk ulotny.

4I AUJ, S II 785, Młodzież Narodowa „Młodość” i „Zjednoczenie”, W pięćdziesiąta rocznice, druk ulotny.

42 S. Kieniewicz, Wspomnienia pośmiertne: Wactaw Tokarz, „Rocznik Towarzystwa Naukowego Warszawskiego" 3I-38 (I938-I945), s. 26I.

43 AUJ, S II 785, NML, Program uroczystego akademickiego obchodu..., druk ulotny. 
W I904 roku na Uniwersytecie Jagiellońskim powstała „Spójnia"44.W swoich teoretycznych założeniach zajmowała się popularyzacją postulatów socjalistycznych, a także samokształceniem. Powstała ona z inicjatywy Polskiej Partii Socjaldemokratycznej Galicji i Śląska Cieszyńskiego ${ }^{45}$. Wraz z napływem studentów z zaboru rosyjskiego gdzie również istniała analogiczna organizacja, w „Spójni” zaczęły się krzyżować różne wpływy socjalistyczne, co doprowadziło w niedługim czasie do podziałów i polaryzacji wśród członków organizacji. W czerwcu i9ıo roku doszło do rozłamu w krakowskiej organizacji „Spójni” na tle kwestii niepodległości - z organizacji odeszli ci działacze, którzy opowiadali się za hasłem walki o niepodległość ${ }^{4}$. Dla pozostałych członków kwestią priorytetową były hasła socjalistyczne i rewolucja robotnicza, która miała być rozwiązaniem kwestii narodowej. Studenci zrzeszeni w tej organizacji współpracowali ze Związkiem Walki Czynnej, uczestnicząc w szkoleniach wojskowych ${ }^{47}$. Ponadto powstała siostrzana organizacja skupiająca uczniów szkół średnich - „Promieniści”, której działalność skupiała się na pracy samokształceniowej. Członkowie „Promienia” wydawali pismo o tej samej nazwie, które nielegalnie kolportowano w zaborze rosyjskim. Warto wspomnieć, że zarówno „Spójnia”, jak i „Promień” współpracowały w tych sprawach, które ich nie dzieliły, a które wypływały z ich lewicowego rodowodu. „Promień” występował przeciwko ugodowej polityce innych organizacji lewicowych, co doprowadziło do konfliktu.

Na X Zjeździe Związku Polskiej Młodzieży Postępowej w Genewie w roku I9II ${ }^{48}$ zarysował się już szerszy spór na tle idei niepodległości, ponieważ delegaci organizacji przyjmujący ten kierunek za główny

44 AUJ, S II 785, NML, Stosunki polityczne wśród młodzieży Wszechnicy Jagiellońskiej, s. I; B. Hillebrandt, Polskie organizacje młodzieżowe..., dz. cyt., s. 34.

45 B. Hillebrandt, Polskie organizacje młodzieżowe..., dz. cyt., s. 34.

46 AUJ, S II 785, NML, Stosunki polityczne wśród młodzieży..., s. 2; B. Hillebrandt, Polskie organizacje młodzieżowe..., dz. cyt., s. 35 .

47 B. Hillebrandt, Polskie organizacje mtodzieżowe..., dz. cyt., s. 35.

48 A. Garlicka, Czasopisma filareckie 1909-1914, cz. II, „Roczniki Historii Czasopiśmiennictwa Polskiego" 9 (I970) z. 2 , s. 202. 
cel jej istnienia opuścili obrady zjazdu49. Dlaczego pozostali delegaci odrzucili hasło niepodległości Polski? Przede wszystkim uważali oni, iż przyczyni się ono do ograniczenia elastyczności organizacji, której członkowie reprezentowali różne poglądy. Ponadto slogan ten - według większości delegatów - nic za sobą nie niósł, był zbyt ogólnikowy. Uczestnicy kolejnego Zjazdu opowiedzieli się również za zerwaniem bojkotu szkół rosyjskich w Królestwie ${ }^{50}$. „Promień” w odezwie wystosowanej prawdopodobnie w I9II roku stwierdził, iż nie dziwi go taka postawa Związku, który już od pewnego czasu nie uwzględniał „bardziej wartościowych elementów naszego społeczeństwa” ${ }^{\mathrm{I}}$. Co więcej, przedstawiciele organizacji stwierdzali, iż z racji tego, że narodowa demokracja również ogłosiła bojkot strajku, „prawica i lewica podały sobie rękę” ${ }^{2}$. „Promień” oskarżał senat UJ, który nie chciał, aby studenci protestowali, o postawy serwilistyczne.

Zarówno „Zet”, jak i „Promień” pozostawały organizacjami studenckimi na Uniwersytecie Jagiellońskim, których zaangażowanie na rzecz niepodległości Polski było największe. Poprzez organizację wieców, a także upamiętnianie ważnych rocznic budzili świadomość narodową wśród studentów, a także starszego pokolenia. Nie należy jednak zapominać również o całościowej zmianie nastrojów w różnych organizacjach studenckich, które ewoluowały wraz ze zbliżającym się wybuchem wielkiej wojny.

Przykładem tego typu organizacji jest „Jagiellonia” powstała w I896 roku ${ }^{53}$. O ile na początku swojego istnienia organizacja ta uchodziła za konserwatywną, a nawet postrzegana była jako zaplecze stańczyków, o tyle już w paragrafie trzecim projektu statutu, odrzuconego przez namiestnictwo w lutym I9I4 roku, pojawiają się już pewne zapisy, które świadczą o zmianie nastawienia:

49 AUJ, S II 785, NML, Do ogótu młodzieży polskiej..., druk ulotny.

50 AUJ, S II 785, NML, Do ogótu młodzieży polskiej..., druk ulotny.

5 I AUJ, S II 785, NML, Koledzy i koleżanki! Niedawno odbyty zjazd..., druk ulotny.

52 AUJ, S II 785, NML, Koledzy i koleżanki! Niedawno odbyty zjazd..., druk ulotny.

53 AUJ, S II 785, Stowarzyszenie Akademickie „Jagiellonia”, Statut Towarzystwa Akademickiego, s. 2. 
Celem Towarzystwa jest w pierwszym rzędzie pielęgnowanie życia towarzyskiego; dalej zaś teoretyczne i w granicach przepisów prawnych akademickich praktyczne kształtowanie się w umiejętnościach politycznych i społecznych. Stowarzyszenie swą działalność rozwija na gruncie religijnym i narodowym, a jako zasadę wszelkiej swej pracy uznaje solidarność narodową ${ }^{54}$.

Powyższy fragment mówi, iż za nadrzędną rolę w swojej działalności „Jagiellonia” uznała interes narodowy, co oznaczało zasadniczą zmianę. Projekt statutu został odrzucony z racji niespełnienia reskryptu C. K. Ministerstwa Wyznań i Oświaty z 20 czerwca I875 roku, mówiącego, że tylko studenci, względnie pracownicy naukowi uniwersytetów mogą być członkami organizacji studenckich. Brakowało również dokładnych sposobów rozwiązywania konfliktów wewnątrz organizacji55. Wydaje się, iż obecność haseł patriotycznych i narodowych w projekcie statutu także mogła się przyczynić się do jego odrzucenia. Z kolei „Polonia” - Towarzystwo Polskiej Młodzieży Katolickiej, widziała przyszłość Polski w odrodzeniu religijnym. O ile w statucie organizacji nie odwoływano się do idei niepodległości, to na podstawie odezwy wydanej przez organizację można stwierdzić, że „Polonia” pragnęła odrodzenia Rzeczypospolitej na zasadach ewangelicznych ${ }^{56}$. Temu też miała służyć formacja religijna członków towarzystwa.

Jak na działalność niepodległościową organizacji reagowały władze Uniwersytetu Jagiellońskiego? Studenci nie byli represjonowani, co wynikało z charakteru tego typu działań. Prowadzenie działalności samokształceniowej czy organizowanie uroczystości upamiętniających ważne rocznice narodowe nie spotykały się z krytyką władz uczelni, wyciąganiem konsekwencji wobec studentów. $\mathrm{O}$ wiele większą uwagę zwracano na działalność radykalnych ugrupowań socjalistycznych, których poczynania kończyły się często wydaleniem słuchaczy z Uni-

54 AUJ, Statut Jagiellonii, rkps, brak numeracji.

55 AUJ, Zakaz namiestnictwa z 6 II I9I4 roku.

${ }_{5} 6$ AUJ, S II 785, Towarzystwo Polskiej Młodzieży Katolickiej Polonia, Koleżanki i koledzy! Na ostatnim wiecu..., druk ulotny. 
wersytetu ${ }^{57}$. Nie oznaczało to bynajmniej, że senat uczelni nie był zainteresowany tego typu działaniami - należy pamiętać, że represje, które spadłyby ze strony władz austriackich, nie dotknęłyby tylko samych studentów, ale całą uczelnię. Dlatego też wszelkie działania studentów starano się kontrolować, a w określonych przypadkach je ograniczać.

Jednym z przykładów limitowania działalności studentów jest zezwolenie na udzielenie jednej z sal uniwersyteckich Komitetowi utworzonemu z Koła Slawistów i Koła Historyków UJ. Komitet ten zajął się organizacją I9 stycznia I9I3 roku uroczystej historyczno-literackiej akademii, celem uczczenia pięćdziesiątej rocznicy powstania styczniowego. Senat UJ użyczył sali organizatorom, jednak pod warunkiem, iż przemawiający na tej uroczystości należeć będą do grona profesorów lub studentów Uniwersytetu ${ }^{5}$. Miało to zapobiec niekontrolowanemu przebiegowi uroczystości np. agitacji politycznej, co mogło spotkać się $z$ dezaprobatą namiestnictwa.

Z kolei wyrazem zainteresowania władz uczelni sytuacją ideowo-polityczną w organizacjach studenckich jest referat doktora Andrzeja Bystronia Stosunki polityczne wśród młodzieży Wszechnicy Jagiellońskiej59. Autor zwrócił w nim uwagę na dominację nurtów socjalistycznego i narodowego wśród studentów i ocenił wpływ na sytuację polityczną napływu studentów z zaboru rosyjskiego po rewolucji I905 roku. Bystroń stwierdził, że około roku ı9ıo był już widoczny podział wśród studentów na kierunki: niepodległościowy i antyniepodległościowy. Obserwacje poczynione przez niego były trafne i zawierały również informacje na temat kontaktów studentów Uniwersytetu ze studentami „emigrantami” - prawdopodobnie z osobami, które musiały uchodzić do Galicji z powodów politycznych z innych zaborów ${ }^{60}$. Aktywność polityczna słuchaczy była więc bacznie monitorowanym przez wykładowców Uniwersytetu Jagiellońskiego aspektem życia studenckiego.

57 Jednym z przykładów takich działań są wydarzenia związane z tzw. zimmermaniadą, zob. J. Buszko, Społeczno-polityczne oblicze Uniwersytetu..., dz. cyt., s. $84-85$.

58 AUJ, S II 85, s. 70-7I.

59 AUJ S II 785, NML, Stosunki polityczne wśród młodzieży..., s. I-2.

6o AUJ S II 785, NML, Stosunki polityczne wśród młodzieży..., s. 2. 
Warto zwrócić uwagę, iż w okolicach roku I9I4 sami pracownicy naukowi organizowali już wykłady, które wzbudzały nastroje patriotyczne - jak np. wykład Wacława Tokarza z roku akademickiego I9I3/I9I4 pt. O powstaniu kościuszkowskim dostępny dla całej publiczności. W pracowni Seminarium Historycznego z kolei toczyły się 29 dyskusje nad przygotowaniem czynu zbrojnego ${ }^{61}$. Kwestia niepodległości Polski ogarnęła w przededniu wybuchu I wojny światowej już cały uniwersytet.

Podsumowując, organizacje studenckie na Uniwersytecie Jagiellońskim w latach I889-I9I4 prowadziły ożywioną działalność niepodległościową w postaci samokształcenia, upamiętniania ważnych rocznic narodowych czy organizowania manifestacji. Do najaktywniejszych organizacji należał Związek Młodzieży Polskiej „Zet”, związany początkowo z narodową demokracją, a także „Spójnia”, skupiająca studentów o poglądach lewicowych. Jak pokazują przykłady powyższych organizacji, kwestia niepodległości Polski doprowadzała niejednokrotnie do wewnętrznych podziałów. Świadczy to jednak o żywotności tego zagadnienia i jego dużym znaczeniu. Wydawać by się mogło, że skala działań studentów w ramach różnych organizacji jest niewspółmierna do wysiłku, jaki był podejmowany przez organizacje paramilitarne w Galicji. Działalność organizacji studenckich przyczyniła się jednak do wykształcenia postaw patriotycznych wśród młodych ludzi, o czym świadczy fakt ich czynnego zaangażowania w szkolenia paramilitarne czy bezpośredni udział w Legionach Polskich po wybuchu I wojny światowej, niezależnie od ich dotychczasowej przynależności politycznej.

6I H. Barycz, Uniwersytet Jagielloński w życiu narodu polskiego, dz. cyt., s. I I2. 


\section{BI BLIOGRAFIA}

I. ŹRÓDŁA

I.I. ŹRÓDłA ARCHIWALNE

Archiwum Uniwersytetu Jagiellońskiego w Krakowie:

AUJ, S II 85, Protokoły posiedzeń Senatu Akademickiego I9I9-I920, s. 70$7 \mathrm{I}$.

AUJ, S II 785, Niepodległościowa Młodzież Ludowa.

AUJ, S II 785, Polska Młodzież Niepodległościowa.

AUJ, S II 785, Stowarzyszenie Akademickie „Jagiellonia”.

AUJ, S II 785, Towarzystwo Polskiej Młodzieży Katolickiej „Polonia”.

\section{I.2. ŹRÓDŁA DRUKOWANE}

Bagiński, H., U podstaw organizacyjnych Wojska Polskiego 1908-1914, cz.I, Warszawa I934.

\section{OPRACOWANIA I ARTYKU£Y NAUKOWE}

Barycz, H., Uniwersytet Jagielloński w życiu narodu polskiego, Wrocław I964. Blombergowa, M., Uczeni polscy rozstrzelani w Katyniu, Charkowie i Twerze, „Analecta. Studia i Materiały z Dziejów Nauki” 9 (2000) z. 2, s. 7-62.

Buszko, J., Społeczno-polityczne oblicze Uniwersytetu $w$ dobie autonomii galicyjskiej (1869-1914), Kraków ig63.

Eisler, J., „Polskie miesiące”, czyli kryzys(y) w PRL, Warszawa 2008.

Fiejdasz-Buczek, L., Bt. cesarz Karol Habsburg (1887-1922). Chrześcijański polityk w stużbie rodziny i narodu, „Roczniki Nauk Prawnych” 36 (2016), s. 7I-89.

Garlicka, A., Czasopisma filareckie 1909-1914, cz. II, „Roczniki Historii Czasopiśmiennictwa Polskiego" 9 (I970) z. 2, s. I97-226.

Halczak, B., Towarzystwo Tomasza Zana w latach 1899-1914, Zielona Góra I996. 
Hillebrandt, B., Polskie organizacje młodzieżowe XIX i XX wieku. Zarys historii, Warszawa i986.

Jakubas, W., Towarzystwo Wzajemnej Pomocy Uczniów Uniwersytetu Jagiellońskiego i jego agendy, „Biuletyn Biblioteki Jagiellońskiej” 63 (2013), s. 213-230.

Kieniewicz, S., Wspomnienia pośmiertne: Wactaw Tokarz, „Rocznik Towarzystwa Naukowego Warszawskiego" 3I-38 (I938-I945), s. 26I-262.

Kozicki, S., Historia Ligii Narodowej. Okres 1887-1907, Londyn I964.

Landau, Z., Młynarski Feliks, w: Polski Słownik Biograficzny, t. XXI, Kraków I976, s. 443-446.

Miziołek, J., Uniwersytet Warszawski. Dzieje i tradycja, Warszawa 2005.

Myśliński, J., „Ognisko” (1889-189o) na tle losów Czytelni Akademickiej Uniwersytetu Jagiellońskiego, „Rocznik Historii Czasopiśmiennictwa Polskiego” I (I962), s. I84-203.

Organizacje młodzieżowe w XX wieku: struktury, ideologia, działalność, pod red, P. Tomaszewskiego, M. Wołosa, Toruń 2008.

Perkowska, U., Uniwersytet Jagielloński w latach I wojny światowej, Kraków I990.

Stańczycy. Antologia myśli społecznej i politycznej konserwatystów krakowskich, red. M. Król, Warszawa ig82.

Stopka, K., Banach, A., Dybiec, J., Dzieje Uniwersytetu Jagiellońskiego, Kraków 2000.

Tabaka, Z., Analiza zbiorowości studenckiej Uniwersytetu Jagiellońskiego w latach 1850-1918. Studium statystyczne, Kraków I970.

Tomicki, J., Polska Partia Socjalistyczna 1892-1948, Warszawa I983.

Waingertner, P., Konspiracja trzech pokoleń. Związek Młodzieży Polskiej „Zet” i ruch zetowy (1886-1996), Łódź 2017.

Wojciechowski Z., Balicki Zygmunt, w: Polski Słownik Biograficzny, t. I, Kraków I935, s. 233-236. 


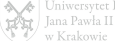

